ENTREVISTA

\title{
ENTREVISTA COM JACQUES GALINIER
}

\author{
Jacques Galinier
}

Jacques Galinier é um antropólogo francês, diretor emérito de pesquisa do Laboratoire $d^{\prime}$ Ethnologie et de Sociologie Comparative (LESC) da Université Paris X Ouest Nanterre La Défense e do Centre National de la Recherche Scientifique (CNRS). Desde 1969, Galinier desenvolve estudos etnográficos pioneiros sobre os Otomi, índios do sul da Huasteca (México Oriental) e sobre os Papago do deserto de Sonora. Inicialmente, reuniu dados sobre a cultura material, as técnicas e a organização social como objeto do seu doutorado (1975) e estudou o sistema ritual e as analogias entre a imagem do corpo e a do cosmos presentes nos discursos indígenas (tese de livre docência, 1985). Jacques Galinier centrou suas atenções nas afinidades e nas discordâncias entre as teorias indígenas e as freudianas. Ao estudar a ontologia otomi, revelou uma epistemologia indígena na Mesoamérica e desenvolveu uma teoria singular no âmbito da Antropologia Psicanalítica.

Ampliou seus horizontes de pesquisa ao coordenar um programa pluridisciplinar de "Antropologia da noite" com Aurore MonodBecquelin (CNRS) e Piero Salzarulo (Universidade de Florença), centrando seus interesses nos rituais de entrada e de saída do sono nos Otomi e nos Mazahua. Com uma reflexão sobre os processos de patrimonialização, Jacques Galinier dirige suas reflexões para a questão indígena, em particular para a construção de um "índio de estado" em Querétaro, México. Da mesma forma, abriu novas frentes etnográficas na Alemanha, no México e no Peru (com Antoinette Molinié), com o estudo dos rituais e das filosofias dos neoíndios, fenômeno associado à Nova Era e do turismo místico na cidade do México e em Cuzco, no Peru. Ao realizar uma análise das performances carnavalescas na região suábio-alemânica (Kinzigtal, Alemanha), encontrou analogias com os rituais dos índios Otomi presentes também na cosmologia, na representação da natureza, na questão dos gêneros e na organização político-ritual.

Galinier acompanha a Antropologia brasileira através do contato com pesquisadores e antigos alunos e, sempre que possível, visita o país. Foi professor visitante no PPGAS-Museu Nacional-UFRJ ainda em 1987, quando ministrou um curso sobre Rituais e Simbolismo com Eduardo Viveiros de Castro. No PPGAS-UFRN já ministrou vários cursos: sobre Antropologia e Psicanálise (1997), sobre os Neoíndios e a ancestralização da Nova Era "asteca" no México atual (2008) e sobre Antropologia da noite (2015).

A entrevista foi realizada no dia 11 de março de 2015 quando da passagem de Jacques Galinier em Natal para participar da XIII Semana de Antropologia e da abertura do Curso de Doutorado em Antropologia Social da Universidade Federal do Rio Grande do Norte, a convite do Departamento de Antropologia. Na ocasião, participou da mesa "Memória, Museus e Política" e ministrou um curso de curta duração no PPGAS/UFRN.

Mais do que uma entrevista formal, o que se segue é uma conversa à bâtons rompus que nos introduz na obra singular de um pesquisador eclético, formado na vieille école, que priorizou a etnografia e soube desenvolver uma proposta teórica inovadora que merece ser mais bem conhecida no Brasil.

Julie A. Cavignac José Glebson Vieira 
Fale-nos sobre sua trajetória acadêmica. Como você começou na Antropologia?

Jacques Galinier: Minha história pessoal com a Antropologia é fruto do acaso, de circunstâncias de um desejo antigo, como muitos jovens da minha época, de me tornar explorador. E, depois, foi seguido do choque que foi a descoberta de Tristes Trópicos. Mas até então nada de muito original, porque acredito ter repetido quase os mesmos caminhos, os mesmos percursos que meus predecessores mais prestigiosos. Tive chance de poder estudar ciência política e sociologia, de me achar confrontado com a obrigação de fazer meu serviço militar ao ser acolhido no México, na missão arqueológica e etnológica ${ }^{1}$ francesa, missão de cooperação com o governo mexicano, que recebia um certo número de jovens formados, em maior quantidade na Arqueologia. O diretor Guy Stresser Péan, que estava nessa função havia muito tempo, tendo chegado ao México em 1934, me falou:

A França tem um setor, a Huasteca, uma vasta região a nordeste do México, na qual temos que fazer uma espécie de survey dos grupos indígenas que estão implantados. Os americanos estão no sul, na região do Chiapas, os italianos no estado de Tlaxcala, os alemães em Puebla, e nessa zona huasteca há uma espécie de buraco negro que é a região Otomi; não foi estudada e não temos nenhuma etnografia dessa zona.

É preciso dizer que nos anos de 1932 a 1934 o grupo Otomi tinha sido estudado verdadeiramente de maneira global pelo antropólogo francês Jacques Soustelle, que se tornaria o meu diretor de tese e que tinha feito um trabalho considerável de percurso, ao mesmo tempo etnográfico e linguístico, até de antropologia física como se fazia na época, na companhia da sua esposa. Mas ele não tinha tido acesso a esta região oriental onde pedia que eu fizesse um trabalho, um percurso. Tinha que escrever uma monografia, o que eu fiz durante três anos, sem deixar o país e passando a maior parte do tempo no campo, nas aldeias indígenas.

\section{Como era fazer etnografia na época?}

Jacques Galinier: Nessa época, tinha feito estudos de etnologia em Bordeaux com Pierre Métais, que havia sido aluno de Maurice Leenhardt na Nova Caledônia e que tinha me formado na tradição da sociologia durkheiminiana. Sobretudo, fora influenciado por Marcel Mauss, do qual era muito próximo, até os seus últimos dias. Essa dupla referência a Leenhardt e a Mauss me acompanhou durante meus primeiros anos de campo e devo reconhecer que possuía um único livro durante meus percursos na Sierra Madre Oriental; era o memorável Manual de etnografia de Marcel Mauss. ${ }^{2}$ Acontece que a Antropologia mexicana, nessa época, ainda era orientada para a descrição e a análise das comunidades indígenas em termos de isolados culturais, na tradição que foi uma das primícias da disciplina e que se inscrevia em linha direta no culturalismo americano. Em 1940, foi criado o Museu de Antropologia do México, a primeira escola de Antropologia, e os meus primeiros professores eram influenciados por essa tendência teórica e metodológica. Então, cheguei em 1969, e me achei um pouquinho em descompasso com os métodos de pesquisa próprios à Antropologia mexicana dessa época que tinha tendência para objetivar a monografia de campo como um trabalho de classificação dos dados, praticando uma espécie de entomologia social.

Depois, apareceu a corrente marxista de inspiração francesa, em particular. Implantou-se uma versão bastante integrista e fundamentalista que reinou durante vários anos na escola de Antropo- 
logia. Nessa época, era impossível entrar lá sem se inscrever diretamente nos passos de Marx, Engels, Stalin etc., porque, nos cursos de Etnologia, semestres inteiros, até seis, eram consagrados à leitura do Capital: leitura do Capital 1, 2, 3, 4, 5, 6, como me assinalaram os estudantes que foram formados nessa escola do marxismo antropológico. Mais tarde, fui fazer uma conferência na Escola Nacional de Antropologia, mas o contexto tinha mudado e era possível entrar na Escola sem ter essa filiação particularmente brutal e mecanicista à sociologia marxista. A corrente considerava, na época, que os índios não existiam enquanto tais, simplesmente eram portadores de sobrevivências arcaicas, portanto, era necessário fazer aliança com o campesinato mexicano para lutar contra o imperialismo internacional e derrubar o Estado. Então, neste contexto um pouco complicado, preferi ficar em campo com os índios Otomi, em vez de participar do combate ideológico nos corredores e na cafeteria da Escola de Antropologia.

Quais eram os temas principais que circulavam na época na França e quais temáticas o levaram a fazer etnografia e a direcionar seus interesses de pesquisa para o México?

Jacques Galinier: Deveríamos falar do contexto da Antropologia francesa nos anos 1960. Podemos dizer que existia uma espécie de conflito entre a Antropologia ensinada em Paris, em torno de Lévi-Strauss e do estruturalismo, que era o quadro de pensamento dominante, mas, de fato, havia também o marxismo como parceiro e antagonista, de que Godelier iria se tornar o representante. Um marxismo que era mais orientado para a análise das dimensões políticas das instituições indígenas do que para o estudo dos conteúdos culturais, das crenças, da religião etc. Esses temas pareciam sem interesse e os primeiros pesquisadores marxistas no México se orientaram para a questão das classes sociais, dos modos de produção, da economia de mercado, mas nem um pouco para o xamanismo, as tradições etc., considerados como sistemas de representação totalmente obsoletos e que deveriam desaparecer através da luta de classes.

Quais eram as principais referências para pensar, por exemplo, a questão do xamanismo e da cosmologia?

Jacques Galinier: Nessa época, entrei relativamente tarde nas questões do xamanismo, pois o projeto que me era confiado consistia primeiramente em fazer o levantamento etnográfico de todos os aspectos culturais das comunidades indígenas nas quais me encontrava: desde a moradia, a organização social, a economia, o parentesco, a organização política, religiosa até a mitologia, os rituais etc.

\section{É um modelo malinowskiano?}

Jacques Galinier: Mais antigo do que isso! É um modelo bastante arcaico de visão da etnografia. Isto corresponde mais ao modelo de Mauss, poderíamos dizer assim. Em particular, porque o diretor da missão francesa tinha uma formação de naturalista. Nos anos 1930, na França, podia-se cursar etnologia nas faculdades de Letras, nas Humanidades, e também nas faculdades de Ciências como uma subdisciplina da antropologia física e da pré-história. Então, ele tinha mais essa orientação e, ao mesmo tempo, a título pessoal, ele era completamente oposto à tradição filosófica ou de inspiração filosófica lévi-straussiana que reinava em Paris. Para falar a verdade, fui engajado por uma razão bem particular: era porque eu morava na província e não em Paris! Então, ele não queria ter um aluno de Lévi-Strauss com ele. Ele não era marxista, era um naturalista da velha escola, 
do final do século XIX, ele fez trabalhos de Arqueologia, de Antropologia física, de Etnografia e um pouco de Linguística.

Aproximava-se do projeto de Paul Rivet então?

Jacques Galinier: Correspondia mais ao projeto de Rivet, ${ }^{3}$ que havia aceitado chegar ao México. Então, eu me encontrava no final dos anos 1960 engajado num projeto que fora formado no início do século XX. Representava um pouco o final de um período da Antropologia, de uma Etnografia bastante arcaizante, e que continuei a fazer depois.

Você recebeu uma bolsa para financiar suas pesquisas?

Jacques Galinier: Eu tinha bolsa porque eu era militar; se chamava Cooperação. Com uma bolsa militar e depois civil, passei três anos no México. Voltei por um ano à França e passei ainda outros três anos no México; entrei no CNRS residindo ao mesmo tempo no México... Minha primeira tese (tese de doutorado de terceiro ciclo) era monográfica. Chama-se "Os índios da Sierra Madre, a comunidade Otomi". Ela foi publicada em espanhol e francês. ${ }^{4} \mathrm{~A}$ segunda tese é sobre o xamanismo, os rituais, a pessoa, a cosmologia. Esta tese foi publicada em francês, espanhol e inglês (nos Estados Unidos). ${ }^{5}$ Ela se chama "A metade do mundo". Jacques Soustelle ${ }^{6}$ foi meu diretor, fui aprovado em 1985.

Como aconteceu essa mudança de direcionamento ou de orientação? Por que você abandonou o modelo clássico que você poderia ter retomado?

Jacques Galinier: Essa mudança aconteceu, de fato, em função do tipo de material que encontrei em campo e nos quais os índios Otomi me orientaram. Considero que foram os índios os meus primeiros diretores de tese, na medida em que a questão do corpo, da pessoa, do xamanismo são as chaves para poder entender o sistema social de parentesco, a cosmologia, a relação entre os vivos e os mortos. O fato é que essa sociedade foi durante muito tempo dominada, subjugada ou vassalizada pelos Astecas, mas tinha conseguido conservar um patrimônio cultural muito forte, de tradição pré-hispânica, graças às estratégias de camuflagem e de resistência à política do vice-reino, à política missionária, à evangelização. E, mesmo hoje, resistem à integração à sociedade global, apesar das migrações, das relações entre o México e os Estados Unidos, pois os Otomi têm um papel importante na economia norte-americana. Por exemplo, uma grande cidade turística, na Flórida, que se chama Clearwater, foi construída quase inteiramente pelos Otomi. Eles estão lá. É uma comunidade que vive na Flórida; o governo americano quis expulsar os migrantes clandestinos, mas a polícia da cidade de Clearwater pediu para eles ficarem porque toda a economia local, os grandes hotéis - Hilton, Mariott, Sheraton etc. - funcionavam unicamente com a presença dos Otomi. Então, podemos seguir a sua trajetória desde a época pré-hispânica, a colônia, a época moderna, e agora através das migrações internacionais.

Foi nessa época que você iniciou suas pesquisas sobre o ritual e a cosmologia? Jacques Galinier: Isso foi depois: passei longos anos... 7, 8, 10 anos com trabalho etnográfico de base. Mas, ao mesmo tempo, tinha aprendido a língua, tinha começado a acumular materiais sobre toda essa dimensão do culto, da religião indígena, e procurava entender um pouco o sentido, que me parecia muito opaco, muito complicado. Foi a partir daí que iniciei o estudo das representações da pessoa, do corpo. É o que chamei, mais tarde, de teoria indígena do inconsciente. 
Você poderia desenvolver um pouco este ponto?

Jacques Galinier: Após ter abordado a questão do colonialismo, da história, fui trabalhar nos arquivos e me dediquei à paleografia dos textos que achei nos arquivos nacionais mexicanos, textos dos séculos XVI e XVII. Mas após meus primeiros anos de campo dedicados à etnografia sem deus, sem quase nenhuma mitologia, pois tinha sido orientado para descrever a cultura material e a organização social, faltava explorar tudo o que se chama no México de cosmovisão, e isto guardei para um segundo tempo; foi ali que entrei verdadeiramente no estudo do xamanismo e da religião.

Você poderia resumir em algumas palavras como é essa religião?

Jacques Galinier: Os Otomi têm a particularidade, entre as populações da Mesoamérica, de serem os últimos, com seus vizinhos nahua, tepehua, a conservar representações antropomorfas das suas antigas divindades. É o que se chama em espanhol regional de ídolos, que são personagens feitos em papel de casca de ficus. Com o auxílio da tesoura, o xamã corta essas figuras para os rituais terapêuticos, os rituais de fertilidade agrária ou de bruxaria. Essa particularidade é uma via de acesso, a via privilegiada para entender a visão do inframundo otomi. Concentrei-me no trabalho xamânico, convivendo com os especialistas, os experts indígenas, compartilhando o seu cotidiano, acompanhando-os nas suas peregrinações, na cura terapêutica. E foi a partir daí que me dei conta de que a complexidade do sistema xamânico não podia ser resolvida a não ser pela referência à imagem do corpo e da pessoa; em particular, tinha que levar em conta elementos interiores que dizem respeito à vida psíquica, os affects.
Uma noção que me pareceu muito complexa no início, mas que era necessário esclarecer, é o que eles chamam de "saco velho", que é ao mesmo tempo uma espécie de receptáculo, de matriz situada embaixo do corpo, invisível, em que estão retidas as imagens, as representações, os conteúdos dos seus sonhos que circulam de uma geração à outra. Mas esse "saco velho" é também um personagem ritual que existe no carnaval e que é o dono da fertilidade. É a figura que expressa, de certa forma, a quintessência, a metapsicologia dos Otomi, por meio da ideia de uma separação do corpo dicotomizado entre uma parte superior, que é aquela visível, diurna, masculina, da religião católica, e uma parte inferior, que pertence à tradição indígena; entre o que poderíamos chamar depois de Freud, de pulsão de vida e de pulsão de morte, pois os dois lados estão ligados. Hoje é chamado de "metade do diabo". A metade de deus é católica, a metade do diabo é indígena.

Então, foi esse sistema de representação que comecei a explorar através do que chamei de exegese interna, quer dizer, os comentários que faziam os índios entre si quando não me dirigiam a palavra, isto é, quando não teorizavam para mim o conteúdo das crenças. Não era quando eu perguntava, mas quando eles falavam entre si, em particular, no estado de embriaguez, pois o álcool é devastador, é um fato social que lubrifica as relações entre os indivíduos, é o coadjuvante indispensável dos rituais para o bom funcionamento da sociedade. Foi durante esses momentos de embriaguez, nessas sessões exegéticas muito particulares, que eu consegui gravar suas palavras e me dei conta, efetivamente, que eles tinham duas obsessões nas suas relações: eles falavam de sexo ou de morte, os dois sendo completamente articulados com essa metade do diabo, a metade inferior. 
Então, nessa época, eu era violentamente hostil à psicanálise, a freudiana em particular. É provável que em função da minha formação sociológica, num tempo em que se negava qualquer psicologização do trabalho etnográfico, pois os atores indígenas eram concebidos de maneira totalmente intercambiável, sem entrar no aspecto idiossincrático da pessoa - serão os temas desenvolvidos depois, de forma larga, nos anos 1980-90, sob a etiqueta de antropologia das emoções, por exemplo. Mas nessa época era praticamente hors-sujet (fora de moda). Então, em princípio, havia uma hostilidade violenta contra a psicanálise e, quando voltei para a França nos anos 1985, mais ou menos quando terminei minha tese, comecei a fazer uma psicanálise que foi uma espécie de revelação da relação peculiar que eu havia mantido com os Otomi e de como eles tinham me orientado para esta visão do mundo, tanto horrenda quanto fascinadora, voltada para as trevas, a morte, o culto dos ancestrais, a violência etc. Foi essa visão do mundo que, mais tarde, me fez decidir a estudar a noite como um campo a ser explorado na Antropologia.

Então, depois de me fazerem descobrir a psicanálise, os Otomi me fizeram descobrir a noite e a lua. Lembro-me que, quando criança, passava longas horas a olhar a lua, suas fases, quando ela estava em conjunção, a lua cheia etc. Encontrei nos Otomi essa mesma fascinação durante as longas discussões que tinha com os informantes à noite, na escuridão, olhando para a lua; eles me mostraram que esse tropismo tinha algo de magnético e que havia uma dimensão da investigação antropológica a se desenvolver e que dizia respeito àquele grande buraco negro que é o universo durante a noite quando se instala o mestre do mundo, aquele que se chama em espanhol o "mestre da noite".

Essa longa introdução sobre meu itinerário, sobre meu percurso, provavel- mente explica minha orientação para as coisas da noite e o fato de que procurei afinidades com alguns colegas. Primeiramente, com uma colega de Nanterre, que é etnolinguista, que trabalha no Xingu, nos Trumaï, Aurore Becquelin. Juntos, decidimos montar um seminário chamado "Antropologia da noite" e convidamos colegas de disciplinas um tanto diferentes, como neuro-fisiologistas, médicos, historiadores, um economista, para tentar inventar uma espécie de corpus metodológico programático que nos permitiria a uns e a outros melhor abranger essa face escondida do mundo que a Antropologia standard parecia ignorar. Outros trabalhos foram feitos, em particular nos Estados Unidos, na Europa do Norte, no Japão, e isto nos mostra que é uma tendência agora muito bem instalada. Os conteúdos desses seminários foram publicados num ensaio e uma parte foi reproduzida na revista Current Antropology em 2010.

Esse programa de pesquisa é, ao mesmo tempo, prometedor e muito frustrante, já que nosso projeto foi na sua base não somente pluridisciplinar, mas também interdisciplinar com as ciências duras, como a Neurofisiologia do sono. Tentamos explorar a possibilidade de utilizar os parâmetros que seriam pertinentes, na medida em que as ciências da vida estão querendo uma espécie de assistência logística para interpretar essa dimensão que lhes escapa no seu protocolo de pesquisa, que é a da cultura. Então, decidimos realizar pesquisas de campo. Uma delas foi muito desenvolvida em uma tese de doutorado sobre os Inuit do Nunavut, sobre a longa noite polar. Entre outros resultados, mostrou a importância de um dos segmentos mais complicados para explorar o nictêmero em diferentes latitudes, mas que eram social e culturalmente investidos de maneiras bem distintas. ${ }^{7}$

Outras investigações foram realizadas nas zonas intertropicais, no México. 
Seria necessário também estudar a zona equatorial para entender de que forma a noite, o sono, em particular, são formatados culturalmente de maneira específica, dependendo das regiões, das áreas culturais, segundo os processos históricos, o lugar etc. Também tínhamos na nossa equipe uma pesquisadora que trabalhou com os cabarés parisienses e a fabricação dos corpos das dançarinas do Lido de Paris como um processo de diurnização dos episódios noturnos e, em certa medida, uma domesticação da noite. Há toda uma série de pesquisas de historiadores que foram publicadas recentemente e que mostram também a revolução não somente tecnológica, mas também nas mentalidades, que foi a iluminação das cidades, das metrópoles, a partir do século XVIII, e como este universo da noite foi pouco a pouco domado, setorizado, colonizado e, de certo modo, domesticado.

Gostaria que você falasse sobre suas pesquisas no México, tentando contextualizá-las no que se convencionou chamar de americanismo tropical e de que modo tal campo é visto no México.

Jacques Galinier: O que parece ser interessante na Antropologia mexicana e que se constituiu na onda do culturalismo americano, entre os anos 1920-40, é o fato de que ficou muito tempo marcada, até hoje está, por uma lógica dominante no setor da Arqueologia, da Museografia; e essa posição é ainda bastante presente. Depois houve a influência do marxismo à francesa e a abertura do México para o continente europeu. Houve também uma diversificação das problemáticas. E, curiosamente, presenciamos uma fraca aclimatação do estruturalismo, que não se instalou verdadeiramente, ficando somente à margem. Mais tarde, houve essa virada para o americanismo tropical, em particular no Brasil, que é muito interes- sante porque se fez de maneira bastante rápida em torno dos anos 2000 e, em particular, através dos trabalhos de Eduardo Viveiros de Castro e da equipe do Museu Nacional do Rio de Janeiro.

Posteriormente, houve uma série de trocas entre México e Rio, intercâmbios entre professores, conferências, seminários, e essa ida e volta acadêmica teve como resultado uma diversificação das problemáticas tratadas pelos pesquisadores mexicanos. Foi, e continua sendo, uma espécie de efeito de moda, de fascinação pelo americanismo brasileiro, e pode ser também por uma releitura de Lévi-Strauss através daquela que é feita justamente por Eduardo Viveiros de Castro, notadamente sobre essa posição do último Lévi-Strauss como o inventor do pós-estruturalismo. Há igualmente toda uma série de debates sobre o animismo e os trabalhos de Philippe Descola, mas nesta perspectiva triangular de circulação das ideias entre Brasil, México e França. É uma tendência bastante marcante, nem tanto da Escola de Antropologia mexicana, mas sobretudo da Universidade Nacional Autônoma do México, do Instituto de Investigações Antropológicas.

Por que você escolheu trabalhar a respeito dos neoíndios após ter desenvolvido pesquisas sobre registros clássicos da Antropologia (ritual, xamanismo, simbolismo etc.)? Parece um pouco provocador, não?

Jacques Galinier: Entre minhas reflexões, há esse inquérito que fiz com uma colega especialista na região andina de Cuzco, Antoinette Molinié, sobre os fenômenos que podemos qualificar de neoétnicos ou neoxamânicos. Inscreve-se, ao mesmo tempo, numa pesquisa identitária das populações hispanófonas, não indígenas, e dos adeptos do turismo místico originário dos Estados Unidos ou da Europa continental. É um fenômeno social que 
conhece uma difusão epidêmica hoje, inclusive agora pelo canal do turismo balneário na Riviera Maia e, sobretudo, na capital, no Distrito Federal. Os neoíndios têm essa particularidade de reivindicar serem descendentes de uma população de origem pré-hispânica, da qual seriam os filhos, eliminando, dicotomizando todo o período colonial e reivindicando uma pureza racial em nome de um eugenismo e de um elitismo "astequizante" e mesmo de um negacionismo. Eles consideram que os sacrifícios humanos nunca existiram e alguns deles paqueram com o antissemitismo! É uma ideologia muito complexa, que toma o lugar da religião católica dominante, hoje em crise no México, e que se inscreve numa onda de invenção de uma religião nova para o país, no horizonte do culto da Santa Muerte, um culto que conhece uma explosão muito rápida em todas as cidades do México e na província e que está centrado na violência e nas crenças religiosas.

Quando começamos essas pesquisas com Antoinette Molinié nos anos 1990, e durante longos anos, era impossível discutir esses temas com nossos colegas antropólogos no México, assim como na França. Era uma pesquisa que eles rejeitavam como sem interesse, que parecia irritante, perturbadora, na medida em que não estávamos lidando com verdadeiros autóctones, mas com índios de paetês. Foi bastante difícil admitir essa impossibilidade de comunicar o que nós observávamos através das suas manifestações, por exemplo, a celebração do equinócio da primavera: o dia 21 de março, na pirâmide de Teotihuacan, que agrupa cada ano mais de um milhão de pessoas. É um fenômeno maciço, transnacional, porque há experts religiosos que vêm da Santeria cubana, sufis da Turquia, lamas tibetanos. É uma galáxia muito complexa e muito rica; então, é preciso falar dela porque existe! Infelizmente, o academicismo oficial fazia com que os historiadores se queixassem de que eles canibalizavam seu próprio saber e o nosso, que foi transformado em folhetos, em literatura de cordel. Atualmente, esta espécie de inibição está se dissolvendo e se vê surgirem novos trabalhos muito ricos que tratam deste fenômeno da Nova Era mesoamericana.

Como explicar essa reticência em trabalhar assuntos um pouco novos e um pouco sulfurosos...

Jacques Galinier: Sim é bastante sulfuroso! Sobretudo porque não corresponde ao quadro oficial da Antropologia, que era o de estudar os "índios de verdade", nas suas comunidades, in situ...

E isso não tem a ver com a etnogênese que existe no México como existe aqui no Brasil, que tem a ver com uma certa Antropologia militante?

Jacques Galinier: Sim há isso, e também o fato de que a gente percebeu, através do nosso estudo comparado entre a região de Cuzco e a celebração do solstício de verão, o Intiraimi que, para os neoincas no Peru e os neoastecas no México, tem múltiplas passarelas, convergências entre essas etnogêneses andinas e mexicanas, mas também divergências. Nós percebemos a necessidade de fazer estudos rápidos e atualizados, porque é uma mouvance que se modifica sem parar. Tínhamos formulado no nosso livro uma hipótese que se declarou obsoleta: partimos da ideia de que as comunidades indígenas de base, os "índios de verdade", iriam continuar a se transformar sem a contaminação das ideias neoastecas. Mas acontece que, atualmente, nas comunidades indígenas, se vê surgirem fenômenos de invenção étnica que são copiados da Nova Era. Quer dizer que esse fosso que havia entre a cultura autóctone e as novas culturas urbanas - que nos parecia impossível de 
ser preenchido - está se fechando pouco a pouco; isto é algo novo e a gente não conhece os processos por vir.

Gostaria que falasse sobre a questão dos museus e do patrimônio, retomando algumas reflexões que você realizou na Semana de Antropologia da UFRN, mais precisamente sobre a participação dos antropólogos nesse contexto de museus, e assim pensar sobre as transformações de objetos nos espaços dos museus.

Jacques Galinier: Eu vou falar somente do México. O México dispõe de uma riquíssima tradição museográfica, sobretudo centrada na Arqueologia; e durante muito tempo a Etnografia foi concebida como uma disciplina auxiliar da Arqueologia, minoritária. Seus métodos de apresentação de exposições deviam revelar quais eram os sistemas sociais dos grupos étnicos que eram mostrados nas salas destinadas à Arqueologia. O México teve a sorte, em 1964, de ver construir um museu magnífico, provavelmente um dos mais bonitos do mundo, que é o Museu Nacional de Antropologia, que abriga ao mesmo tempo coleções arqueológicas e vestígios do passado (muito pouco da época colonial) e os testemunhos das sociedades indígenas que constituem o leque do México de hoje. O problema é que essas salas dão necessariamente uma visão não só estereotipada, mas também um pouco petrificada da realidade social: os trajes, os objetos, as moradias reconstituídas, as danças, os rituais que são expostos na visão de um México tal qual era o "mundo de ontem"; tal qual conheci quando eu era jovem.

Haveria um enorme trabalho a fazer para atualizar a apresentação das coleções e também para integrar os índios, eles mesmos, na elaboração e na modernização das salas que são consagradas às comunidades das quais eles são originários. Os conservadores, os curadores do museu, atualmente, estão fazendo um grande esforço para convidar membros das comunidades indígenas para manifestações recorrentes, para a festa dos mortos em particular, o carnaval, para colocá-los, de qualquer forma, em contato com esse mundo do patrimônio nacional, que eles ignoram e que lhes é estrangeiro. Os antropólogos nacionais mexicanos deverão ter um grande papel nesse dispositivo, na medida em que o México é um país que dispõe de uma quantidade incrível de instituições e de pesquisadores especializados em Antropologia, em todos os domínios. Pode-se dizer mesmo que a Antropologia é uma espécie de mega Ministério da Cultura que contribui de maneira muito forte para a invenção de uma identidade nacional mexicana.

Como etnólogo e estrangeiro, fui muitas vezes convidado a participar de debates, de mesas redondas, inclusive para servir de assessor das pesquisas que foram feitas nos museus do México, e acho que este é um ponto de vista que deve ser aprofundado. Houve, sob a égide do Instituto Nacional Indigenista, que se chama agora Comissão de Desenvolvimento Indígena, um grande esforço para buscar, nas comunidades, interlocutores que pudessem intervir mais vezes na organização desses dispositivos. É uma tendência muito encorajadora e que vai provavelmente ter maior importância nesses anos que vêm.

No que diz respeito à outra pergunta, o que acontece com os atores, os neoíndios, em relação a essa instituição museal, o problema é que a sua ideologia entra em conflito violento com a dos arqueólogos que têm o monopólio da análise da apresentação, da difusão e da institucionalização da cultura mexicana. Os neoíndios são considerados como charlatães pelos arqueólogos e pelos antropólogos oficiais. Por enquanto, sua presença 
é puramente virtual nos museus, mas penso que será preciso um dia estabelecer um compromisso e conseguir a aceitação dessas novas formas de etnogênese que também têm um destino que convém levar em conta com a mesma consideração, o mesmo respeito que temos com as "culturas indígenas autênticas".

Na sua visão, quais seriam os temas de fôlego para a Antropologia contemporânea e no futuro? Que conselhos você poderia dar para nossos estudantes?

Jacques Galinier: Represento, pode ser, um dos últimos testemunhos de uma Etnografia antiquada, do final do século XIX, tal qual se praticou ainda no século seguinte. Vamos dizer que eu comecei a trabalhar com ferramentas intelectuais de várias gerações anteriores, e continuo a fazê-lo, mas penso que uma das chaves, que é preciso destacar para os estudantes, é a necessidade de realizar campo de longa duração, mesmo que a tendência atual seja a de fazer campos cada vez mais curtos, cada vez mais esfacelados, inclusive transcontinentais. Mas eu acredito no valor do mergulho em apneia, profundo, nas comunidades, que podem ser também bairros de tradição cultural colonial ou mais modernos. Não sou a favor dessa espécie de pureza epistemológica que seria a dos antropólogos que se negam a ver todos os aspectos chamativos da civilização urbana nos quais todas as sociedades estão agora integradas. A primeira lição então seria estar com as pessoas, ficar com elas, aprender sua língua, e depois começar a buscar, inventar assuntos, temas de estudos; eu acredito que é pelo campo que se aprende que as verdadeiras perguntas geralmente não são nem um pouco aquelas que tínhamos imaginado no início...

\section{E em relação ao método?}

Jacques Galinier: O método depende do domínio da ação, do domínio da pesquisa. Assistimos a um tipo de especialização frenética da disciplina, e parece que quase ninguém tem essa visão enciclopédica das culturas, que era dos nossos ancestrais, porque somos obrigados a fazer muito cedo escolhas em termos de formação, em termos de leituras, e é por isso que a Antropologia agora se fragmenta: Antropologia seguida de um adjetivo - econômica, simbólica, ou outra. Essa hiperespecialização dos pesquisadores pode ser que tenha permitido dar mais densidade e sofisticação às análises, mas, ao mesmo tempo, coloca um problema de comunicação a longo prazo, de compatibilidade entre as teorias e os métodos. Penso, sobretudo, que estamos saindo da sucessão infernal dos "ismos" e que estamos indo para uma disciplina de cruzamentos, de passarelas, longe de uma visão ideológica estrita.

Somos muito agradecidos, Jacques, por esta conversa estimulante que nos permite ter um panorama geral da sua produção bastante diversificada e, ao mesmo tempo, dedicada a uma área cultural determinada; e por nos permitir colocar em perspectiva várias tendências da Antropologia contemporânea, da Antropologia simbólica às questões étnicas, à museologia e ao patrimônio cultural. 
Julie A. Cavignac é Professora Titular do Departamento de Antropologia e do Programa de Pós-Graduação em Antropologia Social (PPGAS) da Universidade Federal do Rio Grande do Norte, Caicó/RN, Brasil.

E-mail: juliecavignac@gmail.com

José Glebson Vieira é professor Adjunto do Departamento de Antropologia e do Programa de Pós-Graduação em Antropologia Social (PPGAS) da Universidade Federal do Rio Grande do Norte, Caicó/RN, Brasil.

E-mail: jglebson@gmail.com

\section{Notas}

1 A palavra "Etnologia" em francês é sinônimo de "Antropologia", pois designa o campo disciplinar como um todo e não somente o estudo das sociedades indígenas, como é o caso no Brasil.

2 O Manual de Etnografia foi originalmente publicado em 1947 e reeditado em 1967 com o título Manuel d'ethnographie (cours donnés à l'Institut d'Ethnologie de l'Université de Paris), o qual foi compilado por Michel Leiris e Denise Paulme (1947. Paris: Payot. 211pp.). Há duas traduções em língua portuguesa: uma de 1972, pela Editorial Pórtico, e outra, de 1993, pela Dom Quixote, ambas em Lisboa.

3 Etnólogo e americanista francês, Paul Rivet fundou o Museu do Homem e o Instituto e Museu de Antropologia de Bogotá. Teve uma atuação significativa nos estudos etnológicos sobre os povos ameríndios a partir de pesquisas na América do Sul, mais precisamente no Equador, onde realizou missão científica no período de 1901 a 1906.

4 A primeira tese de Jacques Galinier, N'yûhû - Hiérarchie sociale et tradition chez les Indiens Otomi du sud de la Huasteca, foi traduzida para o espanhol e publicada em 1987 pelo Instituto Nacional Indigenista do México com o título Pueblos de la Sierra Madre - Etnografía de la comunidad otomí.

5 A segunda tese, La Mitad del Mundo-Cuerpo y cosmos en los rituales otomíes, foi publicada em 1990 pela UNAM-CEMCA-INI do México e, em 1997, foi publicada a versão francesa, La moitié du monde - Le corps et le cosmos dans le rituel otomi, pela Presses Universitaires de France; em 2004, saiu a versão americana pela Boulder da University Press of Colorado e que tem o seguinte título: The world below - Body and Cosmos in Otomi Indian Ritual. 
6 Jacques Soustelle foi um etnólogo francês dedicado ao estudo de populações indígenas no México, onde realizou pesquisa de campo e missões científicas nas décadas de 1930 e 1940, especialmente entre os Otomi (La famille otomi-pame du Mexique central, 1937), os Lacandones de Chiapas (La culture matérielle des Indiens Lacandons, 1937) e o povo asteca. Ao lado de Paul Rivet, foi um dos fundadores do Museu do Homem, tornando-se vice-diretor. Ensinou no Collège de France, onde proferiu diversas palestras e ministrou vários cursos sobre o pensamento cosmológico dos antigos mexicanos, compondo um livro clássico publicado em 1940, La pensée cosmologique des anciens mexicains. Há alguns livros de Soustelle traduzidos no Brasil, como, por exemplo, Os astecas na véspera da conquista espanhola, pela Companhia das Letras em 1990, e A civilização asteca, em 2002 pela Jorge Zahar.

7 O exemplo dos Inuit do círculo polar ártico é interessante para entender como as sociedades levam em conta a totalidade dos eventos que acontecem entre o pôr e o nascer do sol. Tal definição astronômica não convém para eles, pois a noite pode durar seis meses. Essa sociedade, que detesta o sono e procura se manter acordada, desenvolveu dispositivos originais de domínio da escuridão. Para saber mais sobre o assunto, ver J. Mac Donald (1998. The Arctic Sky, Inuit Astronomy, Star Lore and Legend, co-published by the Nunavut Arctic Research and The Royal Ontario Museum. 313 pp.).

\section{Principais publicações}

GALINIER, Jacques \& MOLINIÉ, A. 2013 [2006]. The Neo-Indians: A Religion for the Third Millenium. Boulder: University Press of Colorado.

GALINIER, Jacques; BIDOU, P. \& JUILLERAT, B. (eds.). 2005. Anthropologie et psychanalyse: regards croisés. Paris: Éditions de l'École des Hautes Études en Sciences Sociales.

GALINIER, Jacques. 2011. Une nuit d'épouvante: Les Indiens Otomi dans l'obscurité. Nanterre: Société d'Ethnologie.
GALINIER, Jacques. 2009. El Espejo otomí: De la etnografía a la antropología psicoanalítica. México: CEMCAUNAM-CDI.

GALINIER, Jacques. 2006. "L'anthropologie hors des limites de la simple raison - Actualité de la dispute entre Kant et Herder". L'Homme, 179:146164.

GALINIER, Jacques. 1997. La moitié du monde: le corps et le cosmos dans le rituel des Indiens otomi. Paris: Presses Universitaires de France. 


\section{Artigos e livros disponíveis na internet (com acesso livre)}

GALINIER, Jacques. 2013. "Alamentação do mestre com cabeça de velho: como se escreve a história na região Otomi". Vivência - Revista de Antropologia, 42:143-152. Disponível em: http://www.periodicos.ufrn.br/ vivencia/issue/view/362.

GALINIER, Jacques. 2011. "Iconografía otomí y nomadismo del sujeto". Alteridades, 2011, vol.21, no.42, 167-175. Universidad Autónoma Metropolitana, Unidad Iztapalapa, Distrito Federal, México. Disponível em: http://www.redalyc.org/articulo. oa? id $=74722745012$

GALINIER, Jacques et al. 2010. "Anthropology of the Night Cross-Disciplinary". Current Anthropology, 51 (6):819-847. Disponível em: http:// www.jstor.org/stable/10.1086/653691.

GALINIER, Jacques. 2008. "Transferência e contratransferência; as novas cadeias operatórias da Antropologia na França". Mesa Redonda 27 - A Antropologia francesa do sec. XX e sua recepção na Antropologia brasileira contemporânea. 26'a RBA, Porto Seguro, BA. Anais da 26 RBA.
Brasilia: Editora da ABA. Disponível em: http://www.abant.org.br/conteudo/ANAIS/CD_Virtual_26_RBA/ mesas_redondas/trabalhos/MR\%20 27/jacques $\% 20$ galinier.pdf.

GALINIER, Jacques. 2001. "Una mirada detrás del telón. Rituales y cosmovisión entre los otomíes orientales". In: Johanna Broda \& Felix Baez-Jorge (eds.), Cosmovisión, ritual e identidad de los pueblos indígenas de México. México: Consejo Nacional para la Cultura y las Artes Fondo de Cultura Económica. pp. 453-484. Disponível em: http://www.gbv.de/dms/sub-hamburg/333124944.pdf.

GALINIER, Jacques. 2000. “Deux sexes, dix genres". L'Homme, 154-155:749754. Disponível em: http://lhomme. revues.org/60.

GALINIER, Jacques. 1979. N'yũhũ, les indiens otomis. Hiérarchie sociale et tradition dans le Sud de la Huasteca. México: Mission archéologique et ethnologique française au Mexique, Mexico. Disponível em: http://books. openedition.org/cemca/3685. 